\title{
UJI EFEKTIVITAS ANTIINFLAMASI SUSPENSI EKSTRAK DAUN BAYAM DURI (Amaranthus spinosus L.) TERHADAP TIKUS PUTIH (Rattus norvegicus) YANG DIINDUKSI KARAGENAN
}

\author{
Rizki Rahmah Fauzia ${ }^{*}$, Ahmad Azrul Zuniarto² \\ 1,2Sekolah Tinggi Farmasi YPIB Cirebon \\ *Korespondensi: Jl. Perjuangan Majasem Cirebon, Email: kikirahmah88@gmail.com
}

\begin{abstract}
ABSTRAK
Latar belakang: Daun Bayam Duri merupakan salah satu tanaman yang mempunyai aktivitas farmakologi yaitu untuk menghilangkan rasa nyeri dan sebagai antiinflamasi. Inflamasi merupakan suatu respon protektif normal terhadap luka jaringan yang disebabkan oleh trauma fisik, zat kimia yang merusak, atau zat-zat mikrobiologik. Pada penelitian ini yang menyebabkan inflamasi adalah karagenan yang disuntikkan pada tikus putih.

Tujuan Penelitian: Penelitian ini bertujuan untuk mengetahui apakah ekstrak dan suspensi ekstrak daun bayam duri (Amaranthus spinosus L.) bermanfaat menurunkan volume udema dan untuk mengetahui pada konsentrasi berapakah ekstrak dan suspensi ekstrak daun bayam duri (Amaranthus spinosus L.) menurunkan volume udema pada kaki tikus putih jantan (Rattus norvegicus).

Metode: Subjek penelitian 24 ekor tikus putih jantan (Rattus norvegicus) dengan berat badan \pm 200 gram. Tikus putih dibagi menjadi 2 kelompok besar dengan 12 ekor tikus untuk uji pendahuluan dan 12 ekor untuk perlakuan. Penelitian dilakukan selama 6 jam. Dari data volume udema dihitung AUC (Area Under the Curve) yaitu luasan daerah di bawah kurva antara ratarata volume udema terhadap waktu dan persen daya antiinflamasi. Data dianalisis menggunakan uji analisis statistik ANOVA, dan uji $T$ - test.

Hasil: Berdasarkan hasil penelitian didapatkan hasil bahwa ekstrak dan suspensi ekstrak daun bayam duri (Amaranthus spinosus L.) mempunyai efektivitas dalam menurunkan volume udema pada kaki tikus putih (Rattus norvegicus) serta ekstrak konsentrasi 50\% dan suspensi ekstrak daun bayam duri konsentrasi 50\% mempunyai efektivitas paling tinggi dalam menurunkan volume udema pada kaki tikus putih (Rattus norvegicus) dengan persentase penghambatan sebesar $15,63 \%$ dan $28,08 \%$.
\end{abstract}

Simpulan: ekstrak dan suspense ekstrak bayam duri dapat menurunkan volume udema pada kaki tikus putih dan yang paling tinggi efektivitasnya adalah ekstrak dan suspensi ekstrak bayam duri dengan konsentrasi $50 \%$.

Kata Kunci: Suspensi, ekstrak daun bayam duri, udema

\begin{abstract}
Background: Leaves of Thorn Spinach are one of the plants that have pharmacological activity which are to relieve pain and as anti-inflammatory. Inflammation is a normal protective response to tissue injury caused by physical trauma, destructive chemicals, or microbiological agents. In this study, the cause of inflammation was carrageenan injected in white rat.

objective: This study aimed to determine whether extract and suspension of thorn spinach leaf extract (Amaranthus spinosus L.) was useful to decrease volume of edema and to determine concentration of extract and suspension of thorn spinach leaf extract (Amaranthus spinosus L.) decrease volume of edema in male white rat (Rattus norvegicus).

Methode: Study subjects were 24 males white rat (Rattus norvegicus) with weight \pm 200 grams. White rats were divided into 2 large groups with 12 rats for preliminary and 12 rats for treatment. The study was conducted for 6 hours. From the data of edema volume, were calculated AUC (Area Under the Curve) that is the area under the curve between the mean volume of edema against time and percent of anti-inflammatory power. Data were analyzed using ANOVA statistic test, and Ttest.
\end{abstract}

Result: The result showed that extract and suspension of thorn spinach leaf extract (Amaranthus spinosus L.) had effectiveness in decreasing the volume of edema in leg of white rat (Rattus 
norvegicus) and extract concentration of 50\% and suspension of thorn spinach leaf extract concentration of $50 \%$ had the most effectiveness in decreasing volume of edema in leg of white rat (Rattus norvegicus) with inhibition percentage as much as 15,63\% and 28,08\%.

Conclusion: extract and suspension of thorn spinach spinach leaf (Amaranthus spinosus L.) had effectiveness in decreasing the volume of edema in leg of white rat (Rattus norvegicus) and extract concentration of 50\% and suspension of thorn spinach leaf extract concentration of $50 \%$ had the most effectiveness in decreasing volume of edema in leg of white rat (Rattus norvegicus).

Keywords: Edema, suspension, thorn spinach leaf extract

\section{PENDAHULUAN}

Indonesia sebagai salah satu negara yang kaya akan berbagai bahan alam, baik itu tumbuhan maupun hewan sehingga banyak masyarakat Indonesia yang memanfaatkannya sebagai obat tradisional. Pemakaian obat tradisional sebagai salah satu pengobatan alternatif sebaiknya diimbangi pula dengan penelitian tentang kebenaran khasiat dan efek sampingnya agar pemakaian dapat dipertanggungjawabkan. Salah satu bagian dari budaya bangsa Indonesia yang berkaitan dengan pemanfaatan kekayaan alam yaitu pemeliharaan kesehatan dan pengobatan penyakit. Budaya tersebut diperoleh dari pengalaman secara turuntemurun. Aneka ragam tumbuhan di alam sekitar dapat memberikan manfaat kesehatan bagi penggunanya.

Dari masa ke masa obat tradisional mengalami perkembangan yang semakin meningkat, terlebih dengan munculnya isu kembali ke alam (back to nature) serta krisis ekonomi berkepanjangan yang menurunkan daya beli masyarakat. Sementara ini banyak orang beranggapan bahwa penggunaan obat tradisional relatif lebih aman dibandingkan obat sintetis. Walaupun demikian bukan berarti obat tradisional tidak memiliki efek samping yang merugikan.

Perlu diketahui informasi yang memadai tentang ketepatan takaran atau dosis, waktu penggunaan, cara penggunaan, pemilihan bahan secara benar, pemilihan obat tradisional untuk indikasi tertentu agar penggunaannya optimal. Jadi tidak benar, bila dikatakan obat tradisional itu tidak memiliki efek samping, sekecil apapun efek samping tetap ada, namun hal itu bisa diminimalkan jika diperoleh informasi yang cukup.
Obat-obatan tradisional selain menggunakan bahan ramuan dari tumbuhtumbuhan tertentu yang mudah didapat di sekitar pekarangan rumah kita sendiri, juga tidak mengandung resiko yang membahayakan bagi pasien dan mudah dikerjakan (dibuat) oleh siapa saja dalam keadaan mendesak sekali pun. Kemajuan ilmu pengetahuan dan teknologi modern yang semakin pesat dan canggih di zaman sekarang ini, ternyata tidak mampu menggeser atau mengesampingkan begitu saja peranan obat-obatan tradisional, tetapi justru hidup berdampingan dan saling melengkapi. ${ }^{1}$

Inflamasi merupakan suatu respon protektif normal terhadap luka jaringan yang disebabkan oleh trauma fisik, zat kimia yang merusak, atau zat-zat mikrobiologik. Trauma tersebut akan menyebabkan timbulnya reaksi radang seperti bengkak dan nyeri. ${ }^{2}$ Proses inflamasi dimulai dari suatu stimulus yang mengakibatkan kerusakan sel. Sebagai reaksi terhadap kerusakan ini, maka sel tersebut akan melepaskan enzim fosfolipase yang akan menghidrolisis enzim fosfolipasedan menghasilkan asam arakhidonat.

Setelah asam arakhidonat bebas, maka akan segera diaktifkan oleh beberapa enzim diantaranya lipooksigenase dan siklookgenase. Bila jaringan cedera karena terbakar, teririrs, atau karena infeksi kuman maka pada jaringan ini akan terjadi serangkaian reaksi yang merusak jaringan. Reaksi ini juga menyebabkan jaringan yang cedera diperbaiki atau diganti dengan jaringan baru. Rangkaian reaksi yang terjadi pada tempat jaringan yang cedera dinamakan radang. ${ }^{3}$

Obat modern yang biasa digunakan sebagai antiinflamasi adalah obat golongan 
AINS (Antiinflamasi Non Steroid) yang pada umumnya mempunyai efek samping tukak lambung sehingga perlu dicari pengobatan alternatif untuk melawan dan mengendalikan rasa nyeri dan peradangan dengan efek samping yang relatif lebih kecil, misalnya obat yang berasal dari tumbuhan. ${ }^{4}$ Daun Bayam duri mempunyai aktivitas farmakologi yaitu untuk menghilangkan rasa nyeri dan sebagai antiinflamasi dan akarnya dapat digunakan sebagai pereda demam (antipiretik) dan peluruh kencing (diuretik). 5 Tanaman Bayam duri memiliki kandungan kimia yaitu amaranthin, rutin, spinasterol, hentriakontan, tanin, kalium nitrat, kalsium oksalat, garam fosfat, zat besi, serta vitamin $(\mathrm{A}, \mathrm{C}, \mathrm{K}$ dan piridoksin $=$ B6). ${ }^{6}$

Tikus merupakan binatang yang bisa digunakan untuk pengujian antiinflamasi dengan berbagai stimulant kimia. Pada pengujian antiinflamasi tikus distimulasi agar terjadi udema. Salah satu zat yang dapat digunakan sebagai induktor udema adalah karagenan. Karagenan adalah ekstrak Chondrusyaitu suatu polisakarida sulfat dengan molekul besar yang bisa menyebabkan inflamasi jika diinjeksikan secara subkutan pada tikus, sehingga bisa digunakan sebagai induktor inflames. ${ }^{7}$ Untuk mendapatkan data ilmiah mengenai efek antiinflamasi daun Bayam duri, perlu dilakukan dengan penelitian efek antiinflamasi ekstrak daun Bayam duri ini pada tikus.

Berdasarkan uraian diatas, maka penulis tertarik untuk melakukan penelitian dengan judul "Uji Efektivitas Antiinflamasi Suspensi Ekstrak Daun Bayam Duri (Amaranthus spinosus L.) Pada Tikus Putih (Rattus norvegicus) Yang Diinduksi Karagenan" karena dalam hal ini belum pernah ada penelitian tentang tanaman Bayam duri untuk obat antiinflamasi yang pengujiannya dilakukan secara oral pada tikus dengan penginduksi larutan karagenan $1 \%$.

\section{METODE PENELITIAN}

Penelitian ini merupakan penelitian eksperimen dengan rancangan penelitian adalah rancangan acak lengkap (RAL). Penelitian eksperimen adalah suatu penelitian dengan melakukan kegiatan percobaan yang bertujuan untuk menyelidiki kemungkinan saling sebab hubungan sebab akibat dengan cara mengadakan intervasi atau mengenakan perlakuan kepada satu atau lebih kelompok eksperimen, kemudian hasil (akibat) dari intervasi tersebut dibandingkan dengan kelompok yang tidak dikenakan perlakuan (kelompok kontrol). ${ }^{8} \quad$ Penelitian ini menggunakan sumber data primer dan sumber data sekunder.

Populasi dalam penelitian ini adalah tanaman Bayam duri (Amaranthus spinosus L.) dan tikus putih (Rattus norvegicus). Tanaman Bayam duri didapatkandari Desa Liang Julang, Kecamatan Kadipaten, Kabupaten Majalengka. Sedangkan hewan yang akan digunakan yaitu tikus putih jantan dengan berat badan tikus antara 200-250 gr dan mempunyai umur kurang lebih 3 bulan sebanyak 24 ekor.

Desain Penelitian yang dilakukan oleh peneliti adalah sebagai berikut:

1. Persiapan alat dan bahan.

2. Determinasi tanaman Bayam duri (Amaranthus spinosus L.) dengan menggunakan Buku Flora.

3. Pembuatan simplia daun Bayam duri (Amaranthus spinosus L.).

4. Pembuatan ekstrak daun Bayam duri (Amaranthus spinosus L.) dengan cara maserasi menggunakan pelarut etanol $70 \%$.

5. Uji efektivitas antiinflamasi ekstrak daun Bayam duri dengan konsentrasi 10\%, $50 \%$ dan $100 \%$ pada tikus putih.

6. Pembuatan suspensi ekstrak daun Bayam duri dengan konsentrasi yang paling efektif dari 10\%, 50\% atau 100\%. Adapun formula untuk sediaan suspensi ekstrak daun Bayam duri yaitu :

R/ Ekstrak Daun Bayam duri 10\%, 50 \%, dan $100 \%$

CMC Na $1 \%$

Nipagin $0,1 \%$

M.f Susp $100 \mathrm{ml}$

7. Uji efektivitas antiinflamasi suspensi ekstrak daun Bayam duri dengan konsentrasi $10 \%$, 50\% dan 100\% pada tikus putih.

8. Uji Stabilitas suspensi ekstrak daun Bayam duri dengan konsentrasi $10 \%$ 
dan $50 \%$, suspensi nonflamin, suspensi $\mathrm{CMC} \mathrm{Na} 1 \%$ pada suhu $0^{\circ} \mathrm{C}, 25^{\circ} \mathrm{C}$, dan $40^{\circ} \mathrm{C}$

9. Analisa data dan pengolahan data.

Pada penelitian ini terjadinya efektivitas ekstrak daun Bayam duri dilihat dari penurunan volume telapak kaki tikus setiap jam selama 6 jam. $^{9}$ Berikut ini merupakan langkah-langkah uji efektivitas antiinflamasi yang dilakukan pada tikus putih terhadap ekstrak daun Bayam duri dan suspensi ekstrak Bayam duri, diantaranya yaitu: 10

1. Menyiapkan 12 ekor tikus yang sehari sebelumnya telah diadaptasi kandang.

2. Membagi tikus tersebut menjadi 4 kelompok secara acak, setiap kelompok terdiri dari 3 tikus.

3. Tikus dipuasakan selama 18 jam sebelum pengujian tetapi minum tetap diberikan.

4. Kemudian salah satu kaki belakang tikus diberi tanda dengan spidol, diukur volumenya dengan mencelupkan ke dalam tabung air raksa pada alat plestismometer, (tanda pada kaki harus sama) ad tanda batas.

5. Suntikkan penginduksi udema larutan karagenan $1 \%$ sebanyak $0,5 \mathrm{ml}$.

6. Kemudian setelah 1 jam diukur volume kaki tikus setelah diinduksi.

7. Pemberian bahan uji, bagi 9 ekor tikus putih menjadi lima kelompok yaitu untuk konsentrasi $10 \%$ tiga ekor, konsentrasi $50 \%$ tiga ekor, dan untuk konsentrasi $100 \%$ tiga ekor. Kelompok uji 1 diberikan ekstrak daun Bayam duri konsentrasi $10 \%$ sebanyak $2 \mathrm{ml}$, kelompok uji 2 diberikan ekstrak daun Bayam duri konsentrasi 50\% sebanyak 2 ml, kelompok uji 3 diberikan ekstrak daun Bayam duri konsentrasi 100\% sebanyak $2 \mathrm{ml}$, kelompok kontrol negatif diberikan zat pembawa nya yaitu Aquadest, dan kelompok kontrol positif diberikan zat pembanding nya yaitu suspensi nonflamin.
8. Hewan uji diberikan perlakuan secara peroral menggunakan sonde.

9. Kemudian Volume kaki tikus diukur setiap jam selama 6 jam dengan cara memasukkan telapak kaki tikus ke dalam alat plestismometer ad batas tanda pada bengkak yang terjadi pada tikus.

10. Data yang diperoleh dari pengukuran volume telapak kaki tikus setiap waktu pada semua kelompok ditabulasikan. Selanjutnya dibuat kurva hubungan antara rata-rata volume edema dengan waktu ( $\mathrm{t}$ ) sehingga membentuk Area Under Curve (AUC). Nilai AUC selanjutnya dianalisis statistika untuk melihat distribusi data. Jika data terdistribusi normal, dilanjutkan dengan uji ANAVA satu arah dengan taraf kepercayaan 95\% dan uji t untuk melihat perbedaan kelompok. ${ }^{11}$ Nilai AUC masing-masing kelompok perlakuan selanjutnya dirata-ratakan untuk menghitung besarnya daya antiinflamasi yang dimiliki suspensi ekstrak dibandingkan dengan kelompok kontrol negatif (aquades). Besarnya daya antiinflamasi dinyatakan dengan Persen Daya Antiinflamasi (\%DAI).

Selain uji efektivitas antiinflamasi, dilakukan pula evaluasi terhadap sediaan suspensi meliputi uji organoleptis, uji $\mathrm{PH}$, uji viskositas, dan uji sedimentasi. ${ }^{12}$

\section{HASIL PENELITIAN}

Dari hasil determinasi tanaman menunjukkan bahwa bahan uji simplisia yang digunakan dalam penelitian ini adalah benar Bayam duri (Amaranthus spinosus L.) dengan nilai persentase rendemen ekstrak sebesar $26,66 \%$. Untuk hasil pengamatan uji efektivitas antiinflamasi suspensi ekstrak daun bayam duri terhadap tikus putih yang diinduksi karagenan dapat dilihat pada Tabel 1. 
Tabel 1.

Hasil Uji Efektivitas Antiinflamasi Suspensi Ekstrak Daun Bayam Duri Terhadap Tikus Putih Yang Diinduksi Karagenan

\begin{tabular}{|c|c|c|c|c|c|c|c|c|c|}
\hline \multirow[t]{2}{*}{ Kelompok } & \multirow[t]{2}{*}{ Tikus } & \multicolumn{2}{|c|}{ Volume Udema Pada kaki Tikus } & \multicolumn{6}{|c|}{ Volume Udema } \\
\hline & & Volume Awal $\left(\mathrm{V}_{0}\right)$ & Setelah Induksi & V1 & V2 & V3 & V4 & V5 & V6 \\
\hline \multirow[t]{3}{*}{$\mathrm{X} 1$} & I & 0,52 & 0,86 & 0,80 & 0,79 & 0,68 & 0,66 & 0,63 & 0,51 \\
\hline & II & 0,45 & 0,96 & 0,80 & 0,73 & 0,72 & 0,67 & 0,64 & 0,53 \\
\hline & III & 0,23 & 0,79 & 0,66 & 0,63 & 0,60 & 0,58 & 0,53 & 0,51 \\
\hline \multicolumn{2}{|c|}{ Rata-rata } & 0,4 & 0,87 & 0,75 & 0,71 & 0,66 & 0,63 & 0,6 & 0,51 \\
\hline \multirow[t]{3}{*}{$\mathrm{X} 2$} & I & 0,35 & 0,77 & 0,70 & 0,65 & 0,59 & 0,56 & 0,54 & 0,49 \\
\hline & II & 0,31 & 0,90 & 0,59 & 0,57 & 0,53 & 0,52 & 0,50 & 0,45 \\
\hline & III & 0,35 & 0,87 & 0,63 & 0,58 & 0,55 & 0,55 & 0,54 & 0,43 \\
\hline \multicolumn{2}{|c|}{ Rata-rata } & 0,33 & 0,84 & 0,64 & 0,6 & 0,55 & 0,54 & 0,52 & 0,45 \\
\hline \multirow[t]{3}{*}{$\mathrm{K}+$} & I & 0,23 & 0,80 & 0,72 & 0,64 & 0,58 & 0,52 & 0,46 & 0,38 \\
\hline & II & 0,30 & 0,72 & 0,61 & 0,58 & 0,50 & 0,44 & 0,39 & 0,36 \\
\hline & III & 0,26 & 0,74 & 0,60 & 0,56 & 0,51 & 0,46 & 0,43 & 0,39 \\
\hline \multicolumn{2}{|c|}{ Rata-rata } & 0,26 & 0,75 & 0,64 & 0,59 & 0,53 & 0,47 & 0,42 & 0,37 \\
\hline \multirow[t]{3}{*}{$\mathrm{K}-$} & I & 0,36 & 0,90 & 0,85 & 0,82 & 0,74 & 0,61 & 0,55 & 0,45 \\
\hline & II & 0,35 & 1,00 & 1,01 & 0,90 & 0,84 & 0,78 & 0,75 & 0,69 \\
\hline & III & 0,42 & 1,06 & 1,00 & 0,82 & 0,78 & 0,74 & 0,64 & 0,55 \\
\hline \multicolumn{2}{|c|}{ Rata-rata } & 0,33 & 0,37 & 0,98 & 0,95 & 0,85 & 0,79 & 0,71 & 0,65 \\
\hline
\end{tabular}

Keterangan :

X1 : Suspensi ekstrak bayam duri konsentrasi $10 \%$

X2 : Suspensi ekstrak bayam duri konsentrasi 50\%

$\mathrm{K}+\quad$ : Kontrol Positif (Suspensi Nonflamin)

K- $\quad$ : Kontrol Negatif (Suspensi CMC Na 1\%)

V1,V2,dst... : Volume telapak kaki tikus pada jam ke-

Hasil uji kenormalan dan uji homogenitas dari data-data yang didapatkan dengan menggunakan SPSS Versi 21.0 for Windows secara statistik adalah terdistribusi normal, maka dilanjutkan dengan metode Anova satu arah One Way Anova. Dari hasil perhitungan uji ANOVA satu arah, suspensi ekstrak daun Bayam duri (Amaranthus spinosus L.) mempunyai efektivitas antiinflamasi terhadap tikus putih (Rattus norvegicus). Berdasarkan dari perhitungan uji $\mathrm{T}$ diperoleh bahwa ada perbedaan efektivitas suspensi ekstrak daun bayam duri (Amaranthus spinosus L.) pada penurunan volume udema dengan kontrol positif. Ekstrak daun bayam duri mempunyai efektivitas sebagai antiinflamasi pada konsentrasi $100 \%$ dengan presentase daya hambatnya $30,04 \%$ walaupun pada konsentrasi $10 \%$ dan $50 \%$ memiliki efektivitas juga sebagai antiinflamasi pada tikus putih dengan persentase daya hambatnya $13,99 \%$ dan $15,63 \%$.

Evaluasi sediaan suspensi yaitu uji stabilitas dilakukan tiap satu minggu selama satu bulan dengan mengamati secara organoleptis yang meliputi bau, bentuk, warna serta mengamati $\mathrm{pH}$, kekentalan dan sedimentasi dari suatu sediaan pada suhu $0^{\circ} \mathrm{C}, 25^{\circ} \mathrm{C}$, dan $40^{\circ} \mathrm{C}$. Adapun hasil pengamatan uji organoleptis bentuk suspensi dapat dilihat pada Tabel 2, Tabel 3, dan Tabel 4. 
Journal of Holistic and Health Sciences

Vol.1, No.2, Juli-Des e mber 2017 | 113

Tabel 2. Hasil Pengamatan Uji Organoleptis Bentuk Suspensi pada suhu $0^{\circ} \mathrm{C}$

\begin{tabular}{|c|c|c|c|c|c|}
\hline \multirow{2}{*}{$\begin{array}{c}\text { Jenis } \\
\text { Sediaan }\end{array}$} & \multirow{2}{*}{$\begin{array}{l}\text { Karakterisasi } \\
\text { yang diamati }\end{array}$} & \multicolumn{4}{|c|}{ Organoleptis Pada Suhu $0^{\circ} \mathrm{C}$} \\
\hline & & Hari ke -8 & $\begin{array}{l}\text { Hari ke } \\
-15\end{array}$ & $\begin{array}{l}\text { Hari ke - } \\
22\end{array}$ & $\begin{array}{l}\text { Hari ke } \\
-29\end{array}$ \\
\hline \multirow{3}{*}{$\mathrm{X} 1$} & $\mathrm{Bau}$ & $\begin{array}{l}\text { Bau } \\
\text { khas }\end{array}$ & $\begin{array}{l}\text { Bau } \\
\text { khas }\end{array}$ & Bau khas & Bau khas \\
\hline & Warna & Coklat & Coklat & Coklat & Coklat \\
\hline & Bentuk & Kental & Cairan & Cairan & Cairan \\
\hline \multirow{3}{*}{$\mathrm{X} 2$} & Bau & Bau khas & Bau khas & Bau khas & Bau khas \\
\hline & Warna & $\begin{array}{l}\text { Coklat } \\
\text { kehitaman }\end{array}$ & $\begin{array}{l}\text { Coklat } \\
\text { kehitaman }\end{array}$ & $\begin{array}{l}\text { Coklat } \\
\text { kehitaman }\end{array}$ & $\begin{array}{l}\text { Coklat } \\
\text { kehitaman }\end{array}$ \\
\hline & Bentuk & Kental & Kental & Kental & Kental \\
\hline \multirow{3}{*}{$\mathrm{K}+$} & $\mathrm{Bau}$ & Bau khas & Tidak berbau & Tidak berbau & Tidak berbau \\
\hline & Warna & Keruh & Kekuningan & Keruh & Keruh \\
\hline & Bentuk & Kental & Kental & Kental & Kental \\
\hline \multirow{3}{*}{$\mathrm{K}-$} & Bau & Tidak berbau & Tidak berbau & Tidak berbau & Tidak berbau \\
\hline & Warna & Keruh & Keruh & Keruh & Keruh \\
\hline & Bentuk & Kental & Kental & Kental & Kental \\
\hline
\end{tabular}

Keterangan :

$\mathrm{X} 1=$ Suspensi ekstrak daun Bayam duri konsentrasi 10\%

$\mathrm{X} 2=$ Suspensi ekstrak daun Bayam duri konsentrasi 50\%

$\mathrm{K}+\quad=$ Suspensi Nonflamin

$\mathrm{K}-\quad=$ Suspensi $\mathrm{CMC} \mathrm{Na} 1 \%$

Tabel 3. Hasil Pengamatan Uji Organoleptis Bentuk Suspensi pada suhu ${ }^{2} 5^{\circ} \mathrm{C}$

\begin{tabular}{|c|c|c|c|c|c|}
\hline \multirow{2}{*}{$\begin{array}{c}\text { Jenis } \\
\text { Sediaa } \\
\text { n }\end{array}$} & \multirow{2}{*}{$\begin{array}{l}\text { Karakterisasi } \\
\text { yang diamati }\end{array}$} & \multicolumn{4}{|c|}{ Organoleptis Pada Suhu $25^{\circ} \mathrm{C}$} \\
\hline & & Hari ke -8 & Hari ke -15 & Hari ke -22 & Hari ke -29 \\
\hline \multirow[t]{3}{*}{$\mathrm{X} 1$} & Bau & Bau khas & Bau khas & Bau khas & Bau khas \\
\hline & Warna & Coklat & Coklat & Coklat & Coklat \\
\hline & Bentuk & Kental & Cairan & Cairan & Cairan \\
\hline \multirow[t]{3}{*}{$\mathrm{X} 2$} & Bau & Bau khas & Bau khas & Bau khas & Bau khas \\
\hline & Warna & Coklat & Coklat & Coklat kehitaman & Coklat kehitaman \\
\hline & Bentuk & Kental & Kental & Kental & Kental \\
\hline \multirow[t]{3}{*}{$\mathrm{K}+$} & Bau & Bau khas & Tidak berbau & Tidak berbau & Tidak berbau \\
\hline & Warna & Keruh & Kekuningan & Keruh Kekuningan & Keruh Kekuningan \\
\hline & Bentuk & Kental & Kental & Kental & Kental \\
\hline \multirow[t]{3}{*}{ K- } & Bau & $\begin{array}{l}\text { Tidak } \\
\text { berbau }\end{array}$ & Tidak berbau & Tidak berbau & Tidak berbau \\
\hline & Warna & Keruh & $\begin{array}{l}\text { Keruh terdapat } \\
\text { endapan }\end{array}$ & Keruh & Keruh \\
\hline & Bentuk & Kental & Kental & Kental & Kental \\
\hline
\end{tabular}

Keterangan :

$\mathrm{X} 1=$ Suspensi ekstrak daun Bayam duri konsentrasi 10\%

$\mathrm{X} 2=$ Suspensi ekstrak daun Bayam duri konsentrasi $50 \%$ 
$\mathrm{K}+\quad=$ Suspensi Nonflamin

$\mathrm{K}-\quad=$ Suspensi CMC Na $1 \%$

Tabel 4. Hasil Pengamatan Uji Organoleptis Bentuk Suspensi pada suhu 40 $\mathrm{C}$

\begin{tabular}{|c|c|c|c|c|c|}
\hline \multirow{2}{*}{$\begin{array}{c}\text { Jenis } \\
\text { Sediaan }\end{array}$} & \multirow{2}{*}{$\begin{array}{l}\text { Karakterisasi } \\
\text { yang diamati }\end{array}$} & \multicolumn{4}{|c|}{ Organoleptis Pada Suhu $40^{\circ} \mathrm{C}$} \\
\hline & & Hari ke -8 & Hari ke -15 & Hari ke -22 & Hari ke -29 \\
\hline \multirow[t]{3}{*}{$\mathrm{X} 1$} & Bau & Bau khas & Bau khas & Bau khas & Bau khas \\
\hline & Warna & Coklat & Coklat & Coklat & $\begin{array}{c}\text { Coklat } \\
\text { kehitaman }\end{array}$ \\
\hline & Bentuk & Cairan & Cairan & Cairan & Cairan \\
\hline \multirow[t]{3}{*}{$\mathrm{X} 2$} & Bau & Bau khas & Bau khas & Bau khas & Bau khas \\
\hline & Warna & $\begin{array}{c}\text { Coklat } \\
\text { kehitaman }\end{array}$ & $\begin{array}{c}\text { Coklat } \\
\text { kehitaman }\end{array}$ & $\begin{array}{c}\text { Coklat } \\
\text { kehitaman }\end{array}$ & $\begin{array}{c}\text { Coklat } \\
\text { kehitaman }\end{array}$ \\
\hline & Bentuk & Kental & Kental & Kental & Kental \\
\hline \multirow[t]{3}{*}{$\mathrm{K}+$} & Bau & Bau khas & Bau khas & Bau khas & Bau khas \\
\hline & Warna & Kekuningan & Kekuningan & Kekuningan & Kekuningan \\
\hline & Bentuk & Kental & Kental & Cairan & Cairan \\
\hline \multirow[t]{3}{*}{ K- } & Bau & $\begin{array}{c}\text { Tidak } \\
\text { berbau }\end{array}$ & $\begin{array}{c}\text { Tidak } \\
\text { berbau }\end{array}$ & Tidak berbau & $\begin{array}{c}\text { Tidak } \\
\text { berbau }\end{array}$ \\
\hline & Warna & Keruh & Keruh & Keruh & Keruh \\
\hline & Bentuk & Kental & Kental & Kental & Kental \\
\hline
\end{tabular}

Keterangan :

$\mathrm{X} 1=$ Suspensi ekstrak daun Bayam duri konsentrasi $10 \%$

X2 = Suspensi ekstrak daun Bayam duri konsentrasi 50\%

$\mathrm{K}+\quad=$ Suspensi Nonflamin

$\mathrm{K}-\quad=$ Suspensi CMC Na $1 \%$

Setelah dilakukan uji organoleptis maka dilanjutkan uji stabilitas $\mathrm{pH}$ yang dapat dilihat pada Tabel 5.

Tabel 5. Hasil Uji Stabilitas pH

\begin{tabular}{ccccccc}
\hline Sampel & Suhu & \multicolumn{4}{c}{ Hari ke } & Rata-rata \\
\hline \multirow{3}{*}{$\mathrm{X}_{1}$} & & 8 & 15 & 22 & 29 & \\
\cline { 2 - 6 } & $0^{\circ} \mathrm{C}$ & 5 & 5 & 5 & 5 & 5 \\
\cline { 2 - 5 } & $25^{\circ} \mathrm{C}$ & 5 & 5 & 5 & 5 & 5 \\
\cline { 2 - 5 } & $40^{\circ} \mathrm{C}$ & 5 & 5 & 5 & 5 & 5 \\
\hline $\mathrm{X}_{2}$ & $0^{\circ} \mathrm{C}$ & 5 & 5 & 5 & 5 & 5 \\
\cline { 2 - 5 } & $25^{\circ} \mathrm{C}$ & 4 & 5 & 4 & 4 & 4,25 \\
\cline { 2 - 5 } $\mathrm{K}+$ & $40^{\circ} \mathrm{C}$ & 5 & 5 & 5 & 5 & 5 \\
\cline { 2 - 5 } & $0^{\circ} \mathrm{C}$ & 5 & 5 & 5 & 5 & 5 \\
\cline { 2 - 5 } & $25^{\circ} \mathrm{C}$ & 5 & 5 & 5 & 5 & 5 \\
\cline { 2 - 5 } $\mathrm{K}-$ & $40^{\circ} \mathrm{C}$ & 5 & 5 & 5 & 5 & 5 \\
\hline & $0^{\circ} \mathrm{C}$ & 6 & 6 & 6 & 6 & 6
\end{tabular}




\begin{tabular}{cccccc}
$25^{\circ} \mathrm{C}$ & 6 & 6 & 6 & 6 & 6 \\
\hline $40^{\circ} \mathrm{C}$ & 6 & 6 & 6 & 5 & 5,75
\end{tabular}

Keterangan :

$\mathrm{X}_{1} \quad$ : Suspensi ekstrak daun Bayam duri konsentrasi 10\%

$\mathrm{X}_{2} \quad$ : Suspensi ekstrak daun Bayam duri konsentrasi 50\%

$\mathrm{K}+\quad$ : Suspensi Nonflamin (Kontrol positif)

K- $\quad$ : CMC Na 1\% (Kontrol negatif)

Hasil Uji Kekentalan adalah salah satu uji untuk stabilitas fisik sediaan.
Adapun hasil uji kekentalan sediaan dapat dilihat pada Tabel 6.

Tabel 6. Hasil Uji Kekentalan

\begin{tabular}{ccccccccccccc}
\hline \multicolumn{1}{c}{ Suri } & \multicolumn{10}{c}{ Suhu $0^{\circ} \mathrm{C}$} & \multicolumn{9}{c}{ Suhu $25^{\circ} \mathrm{C}$} \\
Ke- & $\mathrm{X} 1$ & $\mathrm{X} 2$ & $\mathrm{~K}+$ & $\mathrm{K}-$ & $\mathrm{X} 1$ & $\mathrm{X} 2$ & $\mathrm{~K}+$ & $\mathrm{K}-$ & $\mathrm{X} 1$ & $\mathrm{X} 2$ & $\mathrm{~K}+$ & $\mathrm{K}-$ \\
\hline 8 & 29,9 & 116,7 & 98,6 & 77,4 & 21,5 & 96,7 & 87,4 & 69,4 & 15,2 & 88,3 & 50,3 & 58,6 \\
\hline 15 & 28 & 66,9 & 92,9 & 74,6 & 15,4 & 88,7 & 78,1 & 59,7 & 11 & 42 & 33,8 & 29,2 \\
\hline 22 & 20,6 & 66,6 & 87,1 & 58,9 & 8,8 & 29,6 & 32,4 & 17,5 & 10,9 & 31,5 & 27,4 & 28 \\
\hline 29 & 20,2 & 63,1 & 51,6 & 46,5 & 8,4 & 21,7 & 13,9 & 9 & 10,6 & 19,4 & 18,4 & 20 \\
\hline
\end{tabular}

Keterangan :

$\mathrm{X}_{1} \quad$ : Suspensi ekstrak daun Bayam duri konsentrasi 10\%

$\mathrm{X}_{2} \quad$ : Suspensi ekstrak daun Bayam duri konsentrasi 50\%

$\mathrm{K}+\quad$ : Suspensi Nonflamin (Kontrol positif)

$\mathrm{K}-\quad$ : CMC Na 1\% (Kontrol negatif)

Evaluasi sediaan yang terakhir adalah uji sedimentasi. Hasil uji sedimentasi dapat dilihat pada Tabel 7.

Tabel 7. Hasil Uji Sedimentasi

\begin{tabular}{|c|c|c|c|c|c|c|c|c|c|c|c|c|}
\hline \multirow{2}{*}{$\begin{array}{c}\text { Hari } \\
\text { Ke- }\end{array}$} & \multicolumn{4}{|c|}{ Suhu $0^{\circ} \mathrm{C}$} & \multicolumn{4}{|c|}{ Suhu $25^{\circ} \mathrm{C}$} & \multicolumn{4}{|c|}{ Suhu $40^{\circ} \mathrm{C}$} \\
\hline & $\mathrm{X} 1$ & $\mathrm{X} 2$ & $\mathrm{~K}+$ & K- & $\mathrm{X} 1$ & $\mathrm{X} 2$ & $\mathrm{~K}+$ & K- & $\mathrm{X} 1$ & $\mathrm{X} 2$ & $\mathrm{~K}+$ & $\mathrm{K}-$ \\
\hline 8 & 0,46 & 1 & 0,33 & - & 0,4 & 1 & 0,26 & - & 0,6 & 0,6 & 0,26 & 0,26 \\
\hline 15 & 0,6 & 1 & 0,33 & 0,33 & 0,4 & 1 & 0,26 & 0,3 & 0,33 & 1 & 0,26 & 0,33 \\
\hline 22 & 0,4 & 1 & 0,4 & 0,33 & 0,4 & 1 & 0,26 & 0,3 & 0,33 & 0,86 & 0,26 & 0,33 \\
\hline 29 & 0,4 & 1 & 0,4 & 0,33 & 0,6 & 0,93 & 0,33 & 0,33 & 0,46 & 0,86 & 0,93 & 0,33 \\
\hline
\end{tabular}

Keterangan :

$\mathrm{X}_{1} \quad$ :Suspensi ekstrak daun Bayam duri konsentrasi 10\%

$\mathrm{X}_{2} \quad$ : Suspensi ekstrak daun Bayam duri konsentrasi 50\%

$\mathrm{K}+\quad$ : Suspensi Nonflamin (Kontrol positif)

K- $\quad$ : CMC Na 1\% (Kontrol negatif)

\section{PEMBAHASAN}

Inflamasi adalah terjadinya respon terhadap rangsangan yang merusak secara kimia, fisika, dan biologi seperti kerusakan jaringan akibat radiasi panas, infeksi bakteri, dan parasit lainnya. Rangsangan yang merusak tersebut menyebabkan pecahnya sel mast dan melepaskan mediator-mediator radang dan enzim lisosom yang berperan pada proses inflamasi. Mediator yang dilepaskan antara lain histamin, bradikinin, kinin, leukotrin, prostaglandin, dan faktor pembekuan darah. ${ }^{13}$ 
Proses ekstraksi sampel dilakukan dengan cara maserasi karena proses tersebut relatif sederhana, tidak memerlukan peralatan khusus, dan tidak mengeluarkan biaya yang tinggi. Pelarut yang digunakan adalah etanol $70 \%$ dikarenakan dapat melarutkan hampir semua zat, baik polar, semi polar, dan non polar. Selain itu juga etanol dapat mengendapkan protein dan menghambat kerja enzim sehingga dapat terhindar dari proses hidrolisis dan oksidasi.

$$
\text { Pada pengujian aktivitas }
$$

antiinflmasi, telapak kaki tikus dibentuk edema buatan, dimana edema merupakan manifestasi dari inflamasi. Edema yang terbentuk diukur dengan plestimometer. Penambahan volume edema dapat dihitung dengan mengurangi volume telapak kaki pada jam tertentu dengan volume kaki normal. Adanya volume edema merupakan parameter untuk mengukur potensi efek antiinflamasi suatu senyawa yang diuji.

Dalam penelitian ini yang digunakan untuk menginduksi inflamasi adalah karagenan karena ada beberapa keuntungan yang didapat antara lain tidak menimbulkan kerusakan jaringan, tidak menimbulkan bekas, memberikan respon yang lebih peka terhadap obat antiinflamasi. Karagenan sebagai senyawa iritan menginduksi terjadinya cedera sel melalui pelepasan mediator yang mengawali proses inflamasi. Pada saat terjadi pelepasan mediator inflamasi terjadi udem maksimal dan bertahan beberapa jam. Udema yang disebabkan induksi karagenan bertahan selama 6 jam dan berangsur-angsur berkurang dalam waktu 24 jam.

Sebagai Kontrol positif digunakan obat yang telah teruji mempunyai efek daya antiinflamasi, dalam penelitian ini digunakan Nonflamin yang mengandung Tinoridini $\mathrm{HCl}$ yang mempunyai efek farmakologis menstabilkan biomembran terutama pada lisosom yang berhubungan dengan sel atau jaringan yang rusak sewaktu terjadinya peradangan. Efek ditunjukkan dengan semakin kecil nilai AUC berarti sediaan mampu menghambat udema yang terbentuk akibat induksi karagenan. Nilai AUC dianalisis statistic dari hasil uji yang diperoleh. Hasil penelitian menunjukkan suspensi ekstrak daun bayam duri mempunyai kemampuan mengurangi udema. Berturut-turut setelah pemberian konsentrasi 10 dan 50\%. Efek yang paling besar ditunjukkan pada konsentrasi $50 \%$ dengan kemampuan penghambatannya sebesar $28,51 \%$.

Berdasarkan hasil penelitian pada pemberian suspensi ekstrak daun bayam duri dengan 2 konsentrasi yaitu $10 \%$ dan $50 \%$, CMC Na 1\% digunakan sebagai kontrol negatif dan sebagai pembanding/ kontrol positif digunakan suspensi nonflamin. Pengukuran pertama volume telapak kaki tikus ini merupakan pengukuran telapak kaki tikus normal, pengukuran kedua dilakukan setelah diinduksikan dengan karagenan secara subplantar pada telapak kaki sebanyak 0,5 $\mathrm{ml}$. induksi ini bertujuan untuk meningkatkan volume telapak kaki tikus. Setelah dilakukan pengukuran dengan plestismometer didapat hasil yang meningkat pada volume telapak kaki tikus.

Kemudian tahap selanjutnya dilakukan pengujian suspensi ekstrak daun bayam duri (Amaranthus spinosus L.) dengan konsentrasi $10 \%$ dan $50 \%$ yang kemudian diukur volume telapak kaki setiap selang waktu 60 menit selama 6 jam, diperoleh data rata-rata volume penurunan volume telapak kaki tikus masing-masing perlakuan yaitu kontrol negatif CMC Na 1\% sediaan suspensi ekstrak daun bayam duri (Amaranthus spinosus L.) dengan konsentrasi $10 \%$ dan $50 \%$, serta pembanding suspensi Nonflamin. Persentase daya anti inflamasi suspensi ekstrak $10 \%$ adalah $15,74 \%$ dan daya antiinflamasi suspensi ekstrak $50 \%$ adalah $28,08 \%$. Itu berarti konsentrasi $50 \%$ memiliki daya antiinflamasi > dari daya antiinflamasi konsentrasi 10\%. Tetapi pada uji $\mathrm{T}$-testmenunjukkan bahwa $\mathrm{t}$ hitung $>\mathrm{t}$ tabel yang artinya ada perbedaan efektivitas suspensi ekstrak daun bayam duri pada penurunan volume dengan kontrol positif maka dapat dikatakan suspensi ekstrak daun bayam duri tidak memiliki efektivitas antiinflamasi pada tikus putih jantan bisa dikarenakan adanya penambahan suspending agent (CMC Na) sehingga sediaan menjadi rusak. 
Dari data rata-rata penurunan volume telapak kaki tikus yang diperoleh selama 6 jam, dapat terlihat bahwa ada efek antiinflamasi yang dihasilkan. Hal ini disebabkan karena adanya penghambatan enzim siklooksigenase yang disebabkan oleh flavonoid yang tersari dalam ekstrak, dimana flavonoid secara umum mempunyai kemampuan menghambat enzim lipooksigenase dan siklooksigenase.

Selanjutnya dilakukan uji stabilitas fisik suspensi meliputi bau, bentuk, warna, $\mathrm{pH}$, kekentalan dan sedimentasi pada hari ke-8, ke-15, ke-22, dan ke-29. Dari Tabel 2, $3,4,5,6$, dan 7 , didapatkan bahwa pada hari ke-1 dan ke-8 semua sediaan suspensi tetap stabil pada semua suhu yang ditandai dengan tidak adanya perubahan bau, bentuk, warna sedangkan pada $\mathrm{pH}$ mengalami perubahan. Pada hari ke-15, sediaan suspensi mulai mengalami perubahan bentuk dan warna terutama pada suhu $0^{\circ} \mathrm{C}$ dan $25^{\circ} \mathrm{C}$. Pada hari ke-22 dan hari ke-29 semua suspensi tidak stabil yang ditandai dengan adanya perubahan terutama pada bau, bentuk, warna dan $\mathrm{pH}$, terkecuali pada suspensi nonflamin pada suhu $0^{\circ} \mathrm{C}, 25^{\circ} \mathrm{C}$ dan $40^{\circ} \mathrm{C}$ yang masih memiliki pH yang sama dan suspensi CMC $\mathrm{Na} 1 \%$ yang tetap stabil pada suhu $0^{\circ} \mathrm{C}, 25^{\circ} \mathrm{C}$ terkecuali pada suhu $40^{\circ}$ mengalami perubahan $\mathrm{pH}$ dan dari uji kekentalan dan sedimentasi didapat bahwa pada hari ke-1 dan ke-15 semua sediaan suspensi memiliki kekentalan yang tidak terlalu tinggi, sehingga sediaan suspensi mudah dikocok dan dituang.

Pada hari ke-22 dan hari ke-29 semua suspensi tidak stabil yang ditandai dengan kekentalan suspensi yang rendah sehingga sediaan menjadi agak kental dan cair. Sedangkan pada uji sedimentasi hari ke-1 sediaan suspensi stabil pada semua suhu yang ditandai dengan tidak adanya endapan yang terbentuk. Pada hari ke-8, ke15, ke-22 dan ke-29 semua sediaan mengalami perubahan yang ditandai dengan adanya endapan pada bagian bawah. Dari hasil Uji stabilitas suspensi dapat disimpulkan bahwa suspensi ekstrak daun bayam duri tidak stabil karena dari tiap-tiap perlakuan suspense pada suhu $0^{\circ} \mathrm{C}, 25^{\circ} \mathrm{C}$, dan $40^{\circ} \mathrm{C}$ terjadi perubahan yang signifikan baik dari organoleptis bau, bentuk maupun warna dan juga uji $\mathrm{pH}$.

\section{SIMPULAN}

Berdasarkan hasil penelitian yang dilakukan dapat diperoleh simpulan bahwa ekstrak daun bayam duri (Amaranthus spinosus L.) mempunyai efektivitas antiinflamasi pada tikus putih jantan (Rattus norvegicus) dengan konsentrasi ekstrak 50\% yang mempunyai efektivitas paling tinggi untuk antiinflamasi pada tikus putih jantan (Rattus norvegicus). Sedangkan untuk stabilitas sediaan suspensi ekstrak daun bayam duri (Amaranthus spinosus L.) tidak stabil pada suhu rendah dan suhu tinggi serta tidak stabil pada waktu tertentu.

\section{DAFTAR PUSTAKA}

1. Warsiati. Acuan Sediaan Herbal. Cetakan kedua. Jakarta: Badan Pengawas Obat dan Makanan Republik Indonesia; 2013.

2. Adjirni, Sa'roni. Penelitian Antiinflamasi Dan Retoksisitas Akut Ekstrak Akar Carica Papaya L. Pada Tikus Putih. Pusat Penelitian dan Pengembangan Farmasi. Jakarta : Departemen Kesehatan RI; 2008.

3. Azizah, Masayu, Fitriani. Efek Antiinflamasi Dari Ekstrak Kulit Buah Durian (Durio zibethius Murray ) Terhadap Tikus Putih Jantan. Scientia 5 (2). 2015: 74.

4. Narande, Julia Megawati, Wulur, Anne, Yudistira, Adithya. Uji Efek Antiinflamasi Ekstrak Etanol Daun Suji (Dracaena angustifolia Roxb) Terhadap Edema Kaki Tikus Putih Jantan Galur Wistar. Pharmacon Jurnal Ilmiah Unsrat 2 (03). 2013: 15.

5. Hariana, Arief. 262 Tumbuhan Obat dan Khasiatnya. Jakarta: Penebar Swadaya; 2013.

6. Dalimarta, Setiawan. Atlas Tumbuhan Obat Indonesia. Jilid 1. Jakarta: Grup Puspa Swara; 1999.

7. Darmono, S. Farmakologi Eksperimental. Jakarta: UI Press, 2011.

8. Notoatmodjo, Soekidjo. Metode Penelitian Kesehatan. Jakarta: Rineka Cipta; 2010. 
9. Oktiwilianti, Winda, Yurniarni, Umi, Choesrina, Ratu. Uji Aktivitas Antiinflamasi dari Ekstrak Etanol Daun Asam Jawa (Tamarindus Indica L.) Terhadap Tikus Wistar Jantan. Prosiding Penelitian SpeSia Unisba. 2015. Diunduh dari URL Http://karyailmiah.unisba.ac.id pada tanggal 17 Mei 2017 pukul 20.00 WIB.

10. Sutrisna, EM., D. F. Widyasari, dan Suprapto. Uji Efek Antiinflamasi Ekstrak Etil Asetat Buah Semu Jambu Mete (Anacardium occidentale L.) Terhadap Edema Pada Telapak Kaki Tikus Putih (Rattus norvegicus) Jantan Galur wistar yang Diinduksi Karagenan. Biomedika 2(1). 2010: 33-37.
11. Sujana, Prof. Dr. Design dan Analisa Eksperimen Edisi IV. Bandung: Tarsito; 2012.

12. Fitriani, Yeyen Noor, INHS, Cikra, Yuliati,Ninis, Aryantini, Dyah. Formulasi dan Evaluasi Stabilitas Fisik Suspensi Ubi Cilembu (Ipomea batatas $L$ ) dengan Suspending Agent CMC Na dan PGS sebagai antihiperkolesterol. Jurnal Farmasi Sains Dan Terapan 2 (1). 2015:23-25.

13. Dharma, Surya, Adelinda, Santi, Suharti, Netty. Uji Efek Antiinflamasi Ekstrak Etanol Rimpang Jahe (Zingiber officinale Roscoe) pada Tikus Putih Jantan. 2016. Diunduh dari URL Http://jurnalfarmasihigea.org pada 18 Mei 2017 pukul 20.00 WIB. 